\title{
The Pedagogics Competence of Indonesian Language Education Students as Teacher Candidates in Microteaching
}

\author{
Sarmadan', Fitriyani Hali
}

DOI: 10.35445/alishlah.v13i3.773

\begin{tabular}{l} 
Article Info \\
\hline Keywords: \\
Microteaching; \\
Pedagogic competence; \\
Teacher candidates
\end{tabular}

Kata kunci:

Pembelajaran mikro; Kompetensi pedagogic; Calon guru

\begin{abstract}
The pedagogics competence of Indonesian language education students as prospective professional teachers is needed to improve the quality Indonesian language learning process. This study aimed to describe the pedagogics competence of students as prospective professional teachers in the Indonesian language education study program. This research uses a descriptive method. This study's subjects were all seventh-semester students in the Indonesian language education study program who programmed microteaching courses for the 2020/2021 academic year, totalling 34 students. The research data collection uses a pedagogic ability test through a google form. The percentage of students who have pedagogic abilities is reviewed by each indicator, namely: Indicator I of $11.76 \%$, indicator II of $72.06 \%$, indicator III of 57.35 , indicator IV of 23.53 , indicator V of 61.76, indicator VI of 79.41, indicator VII of 64.71, indicator VIII is 48.53, and indicator IX is 58.82. Overall, the percentage of achievement indicators obtained is $53.10 \%$. So, it can be concluded in this study that the pedagogic ability of the seventh-semester students in the Indonesian language education study program is in a low category.
\end{abstract}

\begin{abstract}
Abstrak
Kompetensi pedagogik mahasiswa pendidikan bahasa Indoesia sebagai calon guru professional sangat diperlukaan untuk meningkatkan proses pembelajaran bahasa Indonesia yang berkualitas. Tujuan penelitian ini adalah untuk mendeskripsikan kompetensi pedagogic mahasiswa sebagai calon guru professional pada program studi pendidikan Bahasa Indonesia. Penelitian ini menggunakan metode deskriptif. Subjek dalam penelitian ini adalah seluruh mahasiswa semester VII pada program studi pendidikan bahasa Indonesia yang memprogramkan mata kuliah pembelajaran mikro tahun akedemik 2020/2021 yang berjumlah 34 mahasiswa. Pengumpulan data penelitian ini dengan menggunakan tes kemampuan pedagogik melalui google form. Persentase banyaknya mahasiswa yang mempunyai kemampuan pedagogic ditinjau setiap indikator yaitu: Indikator I sebesar $11.76 \%$, indikator II sebesar $72.06 \%$, indikator III sebesar 57.35, indikator IV sebesar 23.53, indikator V sebesar 61.76, indikator VI sebesar 79.41, indikator VII sebesar 64.71, indikator VIII sebesar 48.53, dan indikator IX sebesar 58.82. Secara keseluruhan indikator persentase ketercapaian diperoleh sebesar 53.10\%. Sehingga dapat ditarik kesimpulan dalam penelitian ini adalah kemampuan pedagodik mahasiswa semester VII pada program studi pendidikan bahasa Indonesia berada pada kategori rendah.
\end{abstract}

\footnotetext{
${ }^{1}$ Universitas Sembilanbelas November Kolaka, Kolaka, Indonesia Email: sarmadan.usnkolaka@gmail.com

2 Universitas Sembilanbelas November Kolaka, Kolaka, Indonesia

Email: fitriyanihali@gmail.com
} 


\section{INTRODUCTION}

Professional teachers are one of the main indicators of the basis of assessment in providing quality education. Good quality education will create quality human resources. A teacher can become a professional teacher with at least four core competencies: pedagogic competence, personality competence, professional competence, and social competence obtained through professional education (Dedih \& Nurajijah, 2018; Dwiningtyas et al., 2003; Yulyani et al., 2020). The four competencies, pedagogics competence,, must be possessed by teachers in carrying out learning in the classroom and outside the classroom. In addition, Yulyani et al. (2020) suggest that the pedagogics competence of teachers occupies the most important place in education and the implementation of learning because teachers play a role in the learning process, where the learning process is the core of the overall educational process involving aspects of teacher competence.

Educators are the creators of the teaching and learning process. They are the persons who will develop a free atmosphere for students to examine what is interesting and express their ideas and creativity within the limits of consistently enforced norms. As a professional, teachers are required to master various learning methods and models and carry out active, effective, and enjoyable learning for their students. The teacher serves as a teacher, supervisor, and as class administrator (Krismiyati, 2017).

Pedagogic competence, according to Law No. 14 of 2005 concerning Teachers and Lecturers article 1, paragraph 10 is a set of knowledge, skills, and behaviours that must be possessed, internalized and mastered by teachers or lecturers in carrying out their professional duties. As for the Government Regulation of the Republic of Indonesia Number 19 of 2005 concerning National Education Standards in the explanation of article 28 paragraph (3) point (a), it is explained that pedagogic competence is the ability to manage student learning which includes an understanding of students, designing and implementing learning, evaluation of learning outcomes, and the development of students to actualize their various potentials. Furthermore, it is also explained that pedagogic competence is the ability of teachers to manage to learn (Bhakti \& Maryani, 2017; Kurniawan \& Astuti, 2017; Saryati, 2014; Sormin, 2016). Pedagogic competence is an important thing that teachers must master because this competence is the main requirement in conducting effective learning for students to achieve educational goals (Bhakti \& Maryani, 2017).

Furthermore, in the National Education Standards, the explanation of article 28 paragraph (3) point (a) states that pedagogics competence is the ability to manage student learning, including understanding students, designing and implementing learning, evaluating learning outcomes, and developing students. Students to actualize their various potentials (Kurniawan \& Astuti, 2017). In terms of the learning process, pedagogics competence is the teacher's ability to manage student learning. Every teacher must realize this to educate the nation's life (Balqis et al., 2014).

Research conducted by Surapranata (2015) in (Bhakti \& Maryani, 2017) shows that the teacher's pedagogic competence in the aspect of learning knowledge competence and the knowledge aspect of developing the potential of students reflective efforts to improve the quality of learning is still low. The 2015 teacher competency test results on 2.430 .427 teachers showed that the national average had not yet reached the target, which was 53.05 of the 55 targets. The professional ability score was 54.77 , while the average value of pedagogic competence was 48.94. The Director-General of Teachers and Education Personnel (GTK) of the Ministry of Education and Culture said that if the UKG results were further detailed for pedagogics competencies, the national average was only 48.94, which is below the minimum competency standard (SKM) of 55. Even for In this pedagogics field, there is only one province whose scores are above the national average and at the same time achieving SKM, namely DI Yogyakarta (56.91).

The facts related to the teacher's pedagogics competence above certainly require strengthening. Because there are still many teachers who do not have the skills to manage to learn well, starting from designing learning activities, managing learning, to evaluating and improving the learning carried out. Systematic efforts to overcome this, such as training and workshops, can be used as alternatives to 
improve teacher skills. However, it is no less important to prepare teacher candidates who are competent in education (Kurniawan \& Astuti, 2017). As for one of the academic activities relevant to preparing the pedagogics competencies of prospective teachers, it can be done through microteaching courses or microteaching undergraduate programs at universities.

Microteaching is a learning method based on performance whose technique is carried out by training the components of basic teaching competencies (teaching skills) in a simplified learning process in terms of teaching competence, material mastery, student management, and time management. Microteaching is directed towards forming teacher competencies as learning agents as contained in Law Number 14 of 2005 (Moerdiyanto, 2005). Meanwhile, Syafi'i (2014) states that basic micro-skills are a training concept that can be used in various stages of professional development of education personnel, both for in-service training and pre-service education. The implementation procedure is simplified to reduce the complexity that is commonly found in the classroom and the teacher gets feedback. Microteaching that is trained intensively will provide benefits for students, especially in the following ways: (1) students become sensitive to phenomena that occur in the learning process, (2) students become more prepared to carry out practical learning activities at school/educational institutions, (3) students can do self-reflection on their competence in teaching, and (4) students become more familiar and understand the competence of teachers so that they can appear as teachers (Moerdiyanto, 2005).

Previous studies on the description of the pedagogics competence of prospective students in microteaching courses were carried out by Inayah (2016) and Linda (2017). The research they did to collect data on pedagogic competence abilities was using a non-test technique in an observation sheet with a Likert scale. Observations were made when students, as prospective teachers did microteaching practices. The observation sheet contains the lesson plans made by students and the application of eight basic teaching skills. In contrast, the other research is an experimental study of the application of learning models to improve pedagogical competence in microteaching courses. Such as research conducted by Zulaeha \& Bahasa (2011) on the application of innovative learning in improving pedagogic competence.

The difference between previous research and this research is that the former was conducted on prospective Indonesian language teacher students. The latter assessed their pedagogical competence using different indicators, specifically nine indicators specified in teacher competencies for junior high school and senior high school teachers. Senior high school is defined in Minister of National Education Regulation No. 16 of 2007. The indicators are as follows: 1) mastering students' physical, moral, spiritual, social, cultural, emotional, and intellectual characteristics; 2) mastering learning theory and educational learning principles; 3) organizing educational learning; 4) utilizing information and communication technology for educational purposes; 5) facilitating students' development of their various potentials; and 6) communicating effectively, empathically, and effectively.

Research on the pedagogics competence of students as prospective teachers is important to find out in detail what aspects or indicators of pedagogics competence are still lacking. So that the results of this study can be a source of reference data to improve and increase the pedagogics competence of students as professional teacher candidates, lecturers can focus on improving these indicators so that the overall achievement of pedagogic competence is optimal in each indicator. Students can apply the knowledge gained from the nine indicators of pedagogic competence when they go to practice Field Experience in junior, senior high schools.

\section{METHODS}

This type of research is descriptive quantitative research. Descriptive research is quantitative research/characteristics using data. Descriptive research is a method of examining a case of thought or a class of events in the present. This research was conducted in May 2021. The respondents in this research were all fifth-semester students programmed microteaching lesson subject at the Indonesian language education study program at Sembilanbelas November Kolaka University, namely 34 students 
for the 2020/2021 academic year. The data collecting in this study using the technique of giving students' pedagogical ability tests in the form of multiple-choice via a google form. The -choice tests are composed of 9 professional teachers' pedagogic competence indicators. Indicators of pedagogics competence along with the number of questions, are shown in table 1.

\section{Table 1. The pedagogic competence test grid for each indicator}

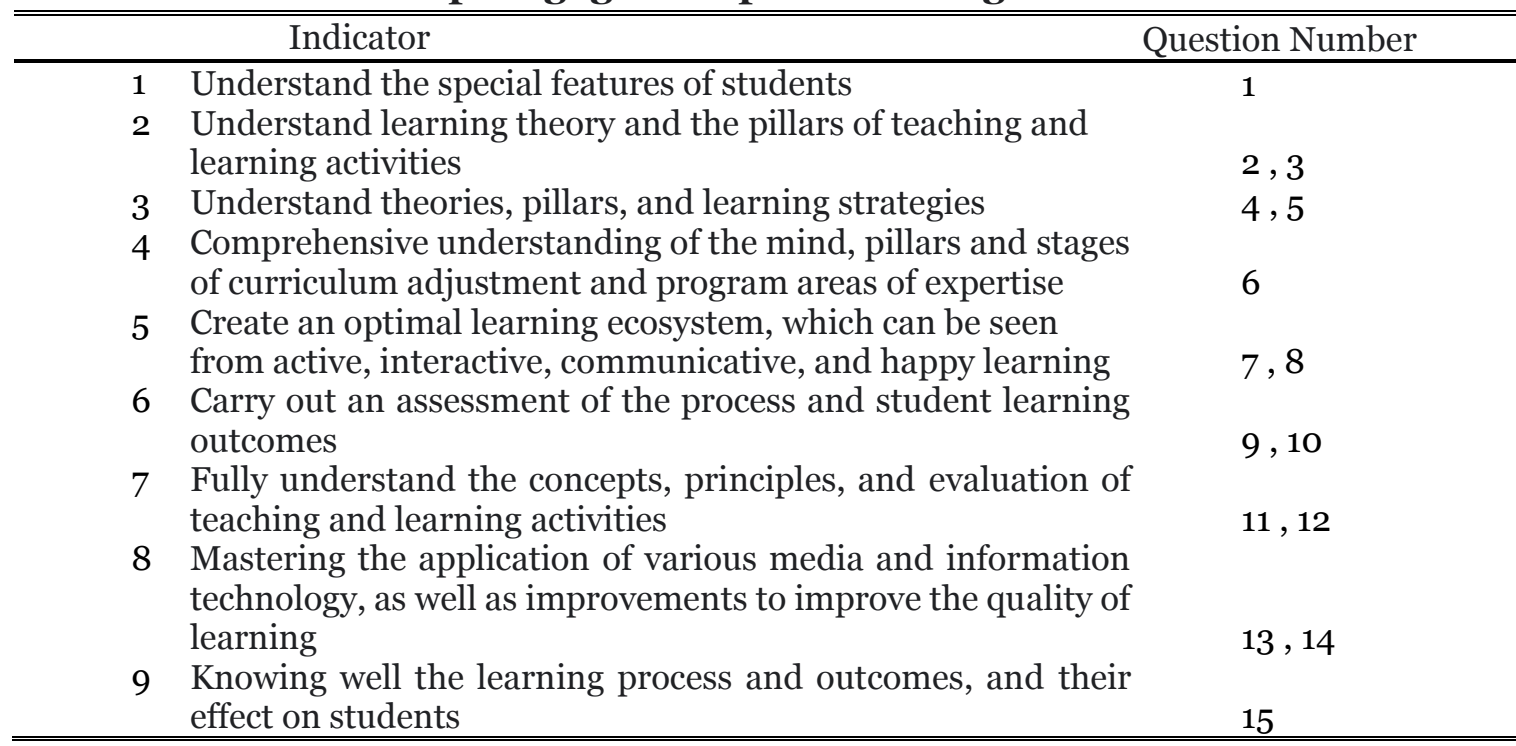

Each question number is worth 1 if it is answered correctly and o if it is answered incorrectly. The value of the pedagogic competence of the results of this study is categorized based on the five-scale criteria according to Arikunto (Vindaswari \& Ulfah, 2018) as shown in table 2.

Table 2. Categorization of students' pedagogical ability scores

\begin{tabular}{ll}
\hline \hline Value & Category \\
\hline $80,00-100,0$ & Very High \\
$66,00-79,99$ & High \\
$56,00-65,99$ & Medium \\
$40,00-55,99$ & Low \\
$0,00-39,99$ & Very Low \\
\hline \hline
\end{tabular}

\section{FINDINGS AND DISCUSSION}

There are nine indicators in this study which can be seen in table 3. The first indicator is made into 1 question, namely the number question. The percentage of answers to each question based on indicators can be seen in table 3 .

Table 3. Percentage of answers to each number of students' pedagogic competence questions

\begin{tabular}{|c|c|c|c|c|}
\hline & \multirow[t]{2}{*}{ Indicator } & \multirow[t]{2}{*}{$\begin{array}{l}\text { Question } \\
\text { Number }\end{array}$} & \multicolumn{2}{|c|}{$\begin{array}{c}\text { Percentage } \\
(\%)\end{array}$} \\
\hline & & & True & False \\
\hline \multirow[t]{2}{*}{1} & Understand the special features of students & 1 & 11.76 & 88.24 \\
\hline & & & 11.76 & 88.24 \\
\hline \multirow[t]{3}{*}{2} & Understand learning theory and the pillars of teaching & 2 & 88.24 & 11.76 \\
\hline & & 3 & 55.88 & 44.12 \\
\hline & & & 72.06 & 27.94 \\
\hline 3 & Understand theories, pillars, and learning strategies & 4 & 50.00 & 50.00 \\
\hline
\end{tabular}




\begin{tabular}{|c|c|c|c|c|}
\hline & & 5 & 64.71 & 35.29 \\
\hline & & & 57.35 & 42.65 \\
\hline \multirow[t]{2}{*}{4} & \multirow{2}{*}{$\begin{array}{l}\text { Comprehensive understanding of the mind, pillars and } \\
\text { stages of curriculum adjustment and program areas of } \\
\text { expertise }\end{array}$} & \multirow[t]{2}{*}{6} & 23.53 & 76.47 \\
\hline & & & 23.53 & 76.47 \\
\hline \multirow[t]{3}{*}{5} & \multirow{3}{*}{$\begin{array}{l}\text { Create an optimal learning ecosystem, which can be } \\
\text { seen from active, interactive, communicative, and } \\
\text { happy learning }\end{array}$} & 7 & 70.59 & 29.41 \\
\hline & & 8 & 52.94 & 47.06 \\
\hline & & & 61.76 & 38.24 \\
\hline \multirow[t]{3}{*}{6} & \multirow{3}{*}{$\begin{array}{l}\text { Carry out an assessment of the process and student } \\
\text { learning outcomes }\end{array}$} & 9 & 88.24 & 11.76 \\
\hline & & 10 & 70.59 & 29.41 \\
\hline & & & 79.41 & 20.59 \\
\hline \multirow[t]{3}{*}{7} & \multirow{3}{*}{$\begin{array}{l}\text { Fully understand the concepts, principles, and } \\
\text { evaluation of teaching and learning activities }\end{array}$} & 11 & 67.65 & 32.35 \\
\hline & & 12 & 61.76 & 38.24 \\
\hline & & & 64.71 & 35.29 \\
\hline \multirow[t]{3}{*}{8} & \multirow{3}{*}{$\begin{array}{l}\text { Mastering the application of various media and } \\
\text { information technology, as well as improvements to } \\
\text { improve the quality of learning }\end{array}$} & 13 & 5.88 & 94.12 \\
\hline & & 14 & 91.18 & 8.82 \\
\hline & & & 48.53 & 51.47 \\
\hline \multirow[t]{2}{*}{9} & \multirow{2}{*}{$\begin{array}{l}\text { Knowing well the learning process and outcomes, and } \\
\text { their effect on students }\end{array}$} & \multirow[t]{2}{*}{15} & 58.82 & 41.18 \\
\hline & & & 58.82 & 41.18 \\
\hline
\end{tabular}

Table 4. Categorization of student pedagogic competence based on each indicator

\begin{tabular}{|c|c|c|c|}
\hline & Indicator & Percentage & Category \\
\hline 1 & Understand the special features of students & 11.76 & Very low \\
\hline 2 & $\begin{array}{l}\text { Understand learning theory and the pillars of teaching } \\
\text { and learning activities }\end{array}$ & 72.06 & High \\
\hline 3 & Understand theories, pillars, and learning strategies & $57 \cdot 35$ & Medium \\
\hline 4 & $\begin{array}{l}\text { Comprehensive understanding of the mind, pillars and } \\
\text { stages of curriculum adjustment and program areas of } \\
\text { expertise }\end{array}$ & 23.53 & Very low \\
\hline 5 & $\begin{array}{l}\text { Create an optimal learning ecosystem, which can be seen } \\
\text { from active, interactive, communicative, and happy } \\
\text { learning }\end{array}$ & 61.76 & Medium \\
\hline 6 & $\begin{array}{l}\text { Carry out an assessment of the process and student } \\
\text { learning outcomes }\end{array}$ & 79.41 & High \\
\hline 7 & $\begin{array}{l}\text { Fully understand the concepts, principles, and } \\
\text { evaluation of teaching and learning activities }\end{array}$ & 64.71 & Medium \\
\hline 8 & $\begin{array}{l}\text { Mastering the application of various media and } \\
\text { information technology, as well as improvements to } \\
\text { improve the quality of learning }\end{array}$ & 48.53 & Low \\
\hline \multirow[t]{2}{*}{9} & $\begin{array}{l}\text { Knowing well the learning process and outcomes, and } \\
\text { their effect on students }\end{array}$ & 58.82 & Medium \\
\hline & Average & 53,10 & Low \\
\hline
\end{tabular}

Using data from tables 3 and 4, it can be concluded that the percentage of students who correctly answered overall indicators on pedagogic ability questions was 53.10 percent. This means that students who design microteaching courses as future teachers are still lacking in pedagogical skills. The reason for this is that students lack the ability to understand the characteristics of students, master concepts, principles and procedures for developing curriculum or program areas of expertise, use media, communication technology, and information, as well as reflective actions, to improve the quality of learning. 
The indicator of comprehending students' unique characteristics is found in number one. In question number 1 , as many as four students (or 11.76 per cent) correctly answered, indicating that students understand that if a student is frequently moody and sad, it is preferable to speak candidly to ascertain this. Meanwhile, 30 students (88.24 per cent) gave incorrect responses, indicating that the student did not understand how to deal with student attitudes or how to determine the cause. The second and third questions contain indicators of an understanding of learning theory and the pillars of teaching and learning activities. In question number 2, as many as 30 (88.24 per cent) students correctly answered, indicating that they had mastered the flow of learning theory, which emphasizes learning as an individual's response system to physical stimuli. While four (11.76 per cent) of the remaining students answered incorrectly, indicating that the student had not mastered the theory of learning. As many as 19 (55.88 per cent) students correctly answered question 3, indicating that students mastered key concepts from Vygotsky's learning theory. Meanwhile, 15 (44.12 per cent) of the remaining students answered incorrectly, indicating that they had not mastered critical concepts from Vygotsky's theory of learning.

Indicators of theories, pillars, and learning strategies are found in questions number 4 and 5 . In question number 4, as many as 17 (50\%) students answered correctly, which means that students mastered the questioning technique that the teacher can do to apply the question and answer method. In comparison, 17 (50\%) other students do not know the questioning technique that the teacher can use to apply the question and answer method. In question number 5, as many as $22(64.71 \%)$ students answered correctly, which means that students mastered the recommended learning principles based on Permendikbud No. 103 of 2014, while 12 (35.29\%) other students answered incorrectly, which means that students do not know the recommended learning principles based on Permendikbud No. 103 of 2014.

Indicators of comprehensive understanding of the mind, pillars and stages of curriculum adjustment and program areas of expertise are in question number 6 . In question number 6 , as many as 8 (23.53\%) students answered correctly, which means students mastered the criteria that must be considered in assessing student responses to problems. While 26 (76.47\%) students answered incorrectly, which means more students do not know the criteria that must be considered in assessing student responses to problems. Indicators of creating an optimal learning ecosystem, which can be seen from active, interactive, communicative, and happy learning, are found in questions number 7 and 8. In question number 7 , as many as 24 (70.59\%) students answered correctly, which means students know the steps of learning the scientific learning approach, while 10 (29.41\%) students answered incorrectly, which means that students do not know the steps of learning the scientific learning approach. In question number 8, as many as 18 (52.94\%) students answered correctly, which means students know about the function of enrichment material, while 16 (47.06\%) students answered incorrectly, which means students do not know about the function of enrichment material.

Indicators of carrying out an assessment of the process and student learning outcomes are found in questions number 9 and 10. In question number 9, as many as 30 (88.24\%) students answered correctly, which means that students know the form of non-authentic assessment, while as many as 4 $(11,76 \%)$ students answered incorrectly, which means that students do not know the form of nonauthentic assessment. In question number 10, as many as 24 (70.59\%) students answered correctly which means that students know the objective understanding of the general principles of assessment of learning outcomes, while 10 (29.41\%) students answered incorrectly, which means that students do not know the objective meaning of general principles of assessment of learning outcomes. Indicators of fully understanding the concepts, principles, and evaluation of teaching and learning activities are questions number 11 and 12. In question number 11 as many as 23 (67.65\%) students answered correctly, which means that students master the types of learning evaluation tools, while as many as 11 (32,35\%) students answered incorrectly, which means that students do not know the types of learning evaluation tools. On question number 12, as many as 21 (61.76\%) students answered correctly, which means students mastered discriminatory power. An item states how far the item may be able to distinguish 
between students who know the answer correctly and students who cannot answer the question., while as many as 13 (38.24\%) students answered incorrectly, which means that students do not know the discriminatory power is a question item stating how far the item may be able to distinguish between students who know the answer correctly and students who cannot answer the question.

Indicators of mastering the application of various media and information technology, as well as improvements to improve the quality of learning, are contained in questions number 13 and 14. In question number 13 , as many as 2 (5.88\%) students answered correctly, which means students mastered the things that need to be done before correcting the question if it turns out that in its manufacture there are still deficiencies or errors found, while as many as 32 (94.12\%) students answered incorrectly which means that many students still do not know what to do before fixing the problem if it turns out that in its manufacture there are still deficiencies or errors. In question number 14 as many as 31 (91.18\%) students answered correctly, which means that mastering the criteria that must be met in the use of teaching aids, while as many as 3 (8.82\%) students answered incorrectly, which means that only a few students did not know the criteria that must be met in the use of teaching aids. Indicators of knowing well the learning process and outcomes and their effect on students are found in question number 15. In question number 15 as many as 20 (58.82\%) students answered correctly which means that students know that the main purpose of the teacher doing reflection activities on learning is improving and developing learning, while as many as $14(41.18 \%)$ students answered incorrectly which means that students do not know the main purpose of the teacher doing reflection activities on learning is to improve and develop learning.

The low pedagogic competence of students, especially on the indicator of understanding the special features of students, an indicator of comprehensive understanding of the mind, pillars and stages of curriculum adjustment and program areas of expertise, and indicator mastering the application of various media and information technology, as well as improvements to improve the quality of learning is due to the lack of reinforcement of material about student pedagogic competencies and the lack of training and assignments on skills. Related to pedagogics competence, in particular, the three indicators are low. This is in accordance with the results of Hali and Herlina's research (2018), which states that one of the causes of the low pedagogic competence of students as prospective teachers is the low motivation of students to increase their pedagogical competence and the lack of training or tasks that require the creativity of prospective teachers to improve their pedagogic competence (Hali \& Herlina, 2018).

Numerous strategies for enhancing students' pedagogic competence, particularly those who program microteaching courses, include the provision of material that strengthens students' pedagogic competence. The findings of Triyono's research indicate that by disseminating pedagogic competence material to students, it is possible to increase students' pedagogic competence (Sahayu et al., 2013). Additionally, by incorporating lesson study learning into microteaching, prospective teacher students' pedagogic competence can be developed and improved (Deswita, 2019; Safriana \& Marina, 2019a, 2019b; Simatupang \& Aryeni, 2018; Untari et al., 2018).

\section{CONCLUSION}

In microteaching courses, Indonesian language education students' pedagogics competence is low. Only indicators of mastering learning theory and learning principles and indicators of mastering concepts, principles, and learning assessment strategies are found among students in the high category of pedagogic competence. However, the pedagogic competence of students who are in the low category are indicators of mastering concepts and principles and procedures for developing curriculum or program areas of expertise and indicators of mastering the use of media, communication technology, and information as well as reflective actions to improve the quality of learning. Students who program microteaching courses can improve their pedagogic abilities in a number of ways, including through the use of lesson study and material reinforcement of pedagogic competence. Only nine indicators of pedagogical competence are described in this study, and the data collected is limited to those who took 
the test. On indicators with very low and low categories, this research can serve as an input for improving, improving, and developing students' pedagogic competencies in order to produce future professional teachers. The Regulation of the Minister of National Education No. 16 of 2007 concerning Academic Qualification Standards and Teacher Competence describes ten indicators of pedagogic competence that can be used by future researchers to dig deeper into professional competence. Students' low pedagogic competence can also be studied by researchers to see if developing learning models can improve these indicators of competence.

\section{REFERENCES}

Balqis, P., Usman, N., \& Ibrahim, S. (2014). Kompetensi Pedagogik Guru Dalam Meningkatkan Motivasi Belajar Siswa Pada. Jurnal Administrasi Pendidikan Pascasarjana Univeritas Syiah Kuala, 2(1), 25-38. http://www.jurnal.unsyiah.ac.id/JAP/article/view/2497/2344

Bhakti, C. P., \& Maryani, I. (2017). Peran LPTK dalam Pengembangan Kompetensi Pedagogik Calon Guru. Jurnal Pendidikan (Teori Dan Praktik), 1(2), 98. https://doi.org/10.26740/jp.v1n2.p98106

Dedih, U., \& Nurajijah, A. I. (2018). Kompetensi Paedagogik Guru Pendidikan Agama Islam Terhadap Motivasi Belajar Siswa Smp. Jurnal Perspektif, 2(1), 72. https://doi.org/10.15575/jp.v2i1.24

Deswita, H. (2019). Lesson Study pada Perkuliahan Microteaching. Mat-Edukasia: Jurnal Pendidikan Matematika, 4(2), 1-9.

Dwiningtyas, A. D., Enoh, \& Mulyani, D. (2003). Analisis Deskriptif tentang Kompetensi Pedagogik Guru TK Berprestasi di Kota Bandung. Prosiding Pendidikan Guru PAUD, 6(2), 149-155. https://doi.org/http://dx.doi.org/10.29313/.v6i2.22604

Hali, F., \& Herlina, H. (2018). Analysis of Pedagogic Competency of Mathematical Education Students in Microteaching Course at the Universitas Sembilanbelas November Kolaka. Journal of Mathematics Education, 3(2), 60-64. https://doi.org/10.31327/jomedu.v3i2.842

Inayah, S. (2016). Analisis Kompetensi Pedagogik Mahasiswa Pada Mata Kuliah Program Latian Profesi I (PLPI). Jurnal Handayani, 5(2), 1-12.

Krismiyati, K. (2017). Pengembangan Sumber Daya Manusia dalam Meningkatkan Kualitas Pendidikan di SD Negeri Inpres Angkasa Biak. Jurnal Office, 3(1), 43. https://doi.org/10.26858/jo.v3i1.3459

Kurniawan, A., \& Astuti, A. P. (2017). Deskripsi Kompetensi Pedagogik guru dan Calon Guru Kimia SMA Muhammadiyah 1 Semarang. Seminar Nasional Pendidikan, Sains Dan Teknologi, 1-7.

Linda, L. (2017). Analisis Penguasaan Kompetensi Pedagogik dan Profesional Mahasiswa Calon Guru Matematika. PYTHAGORAS: Jurnal Pendidikan Matematika, 12(1), 65-75.

Moerdiyanto. (2005). Artikel Jurnal Mikro Teaching (Issue Produktivitas Pembelajaran MIkro).

Safriana, \& Marina. (2019a). Pengembangan Perangkat Pengajaran Mikro Berbasis Lesson Study Untuk Meningkatkan Pedagogical Content Knowledge Mahasiswa Calon Guru Fisika. Jurnal Pendidikan Sains Indonesia (Indonesian Journal of Science Education), 7(2), 79-90. https://doi.org/10.24815/jpsi.v7i2.14643

Safriana, \& Marina. (2019b). Penerapan Microteaching Berbasis Lesson Study Untuk Meningkatkan Kemampuan Mengajar Mahasiswa Calon Guru Fisika. Pros. SemNas. Peningkatan Mutu Pendidikan, 1(1), 480-484.

Sahayu, W., Triyono, S., \& Malia, L. (2013). Instrumen Penilaian Kompetensi Kepribadian Mahasiswa Jurusan Pendidikan Bahasa Jerman FBS UNY.

Saryati. (2014). Upaya Peningkatan Kompetensi Paedagogik Guru Sekolah Dasar. Bahana Manajemen Pendidikan Jurnal Administrasi Pendidikan, 2(1), 669-681.

Simatupang, H., \& Aryeni, A. (2018). Model Pendekatan Lesson Study Untuk Meningkatkan Keterampilan Mengajar Mahasiswa Pada Mata Kuliah Microteaching. Jurnal Biolokus, 1(2), 77. https://doi.org/10.30821/biolokus.vii2.347

Sormin, D. (2016). Kompetensi Guru Dalam Melaksanakan Dan Mengelola Proses Belajar Mengajar Di Pondok Pesantren Darul Mursyidi Desa Sialogo Tapanuli Selatan. FITRAH:Jurnal Kajian IlmuIlmu Keislaman, 2(1), 117. https://doi.org/10.24952/fitrah.v2i1.459

Syafi'i., M. (2014). Implikasi Pembelajaran Mikro Dalam Pengembangan Kompetensi Keguruan. Jurnal Studi Islam, 5(1978-306X), 228-250.

Untari, T., Rahmaniah, R., Islami, A. B., \& Ihsani, B. Y. (2018). Peningkatan Pembelajaran Microteaching Melalui Pendekatan Kolaboratif. Jurnal Prakarsa Pacdagogia, 1(1), 91-100. http://jurnal.umk.ac.id/index.php/JKP 
Vindaswari, R. F., \& Ulfah, A. (2018). Pengembangan Buku Cerita Anak Bergambar Berbasis Nilai-Nilai Kepedulian Bagi Peserta Didik Kelas 2 Sekolah Dasar. Jurnal Fundadikdas (Fundamental Pendidikan Dasar), 1(3), 148. https://doi.org/10.12928/fundadikdas.v1i3.661

Yulyani, Y., Kazumaretha, T., Arisanti, Y., Fitria, Y., \& Desyandri, D. (2020). Implementasi Kompetensi Pedagogik Guru Dalam Pembelajaran Tematik Di Sekolah Dasar. School Education Journal Pgsd Fip Unimed, 1O(2), 184. https://doi.org/10.24114/sejpgsd.v10i2.18545

Zulaeha, I., \& Bahasa, F. (2011). Pengembangan Model Pembelajaran Mikro Inovatif Bagi Peningkatan Kompetensi Pedagogik Calon Guru Bahasa Indonesia. Lingua, 6(2). 
This page is intentionally left blank 